\title{
Severe purulent pericarditis caused by invasive Eikenella corrodens: case report and literature review
}

Wei Wei and Hu Nie*

\begin{abstract}
Background: Eikenella corrodens is a slowly growing gram-negative bacillus that can cause severe invasive disease in human. Although E. corrodens infections in various sites of human body have been well described, pericarditis caused by invasive E. corrodens has rarely been reported.

Case presentation: Here we report the case of a 63-year old male with a complaint of left shoulder pain. The patient was diagnosed as purulent pericarditis by chest computed tomography scan and ultrasound-guided pericardiocentesis, and the pathogen of E. corrodens was identified in the pericardial fluid culture. The clinical condition of the patient deteriorated quickly, and he died right after the drainage surgery even though the pathogen was sensitive to antibiotics treatment.

Conclusion: E. corrodens is a rare pericarditis associated pathogen. Purulent pericarditis caused by E. corrodens presents atypical manifestations and rapid progression of infection in immunosuppressed individuals such as neutropenic patients. Earlier diagnosis and proper drainage surgery with effective antibiotics treatment may improve the prognosis.
\end{abstract}

Keywords: Eikenella corrodens, Infection, Pericarditis

\section{Background}

Eikenella corrodens, a small fastidious, facultative, anaerobic gram-negative bacillus, normally inhabit in dental plaque [1]. Although it is an uncommon cause of infection, its pathogenic potential has been recognized. E. corrodens could independently cause serious infection in both immunocompetent and immunocompromised hosts. Diseases caused by this pathogen include periodontitis, sinusitis, bite wound infections, head and neck infection, respiratory tract infections, abdominal infections, gynecologic infections, meningitis, spinal infection, endocarditis, and osteomyelitis [2-9]. Herein we report a case of purulent pericarditis caused by E corrodens and we also review the literature on $\mathrm{E}$ corrodens infections.
* Correspondence: dr.hu.nie@gmail.com

Emergency Department of West China Hospital, Sichuan University,

Chengdu, China

\section{Case presentation}

A 63-year-old male was admitted to the emergency department with a complaint of left shoulder pain for one month and chest tightness for 3 days. The patient had a history of diabetes mellitus and his glucose was well regulated. Six years prior the patient had been treated with esophagectomy and radiotherapy for esophageal cancer. After the surgery, he had 3 times of following-up gastroscopy examinations, which indicated no evidence of recurrence, while the white blood cell count (WBC) kept in relatively lower level around $3.5 \times$ $10^{9} / \mathrm{L}$. At admission he had no cough, vomiting and abdominal pain.

The patient had a temperature of $37.6^{\circ} \mathrm{C}$, a blood pressure of $123 / 87 \mathrm{mmHg}$, a pulse of $103 \mathrm{bpm}$, a respiratory rate of 20 per minute and an oxygen saturation of $97 \%$ at admission. There was no paradoxical pulse. His jugular veins were slightly distended. Lung auscultation revealed crackles at both lung bases, while the heart sounds were not distant. There was mild edema in both legs. 
The laboratory examination indicated WBC of $12 \times 10^{9} / \mathrm{L}$ and serum procalcitonin level of $1.8 \mathrm{ng} / \mathrm{ml}$, while the liver function tests and serum myocardial markers level (troponin $\mathrm{T}$ and pro-b-type natriuretic peptide) were slightly above normal. Chest computed tomography revealed a massive pyopneumopericardium, a bilateral pleural effusion, and a collapse of the lower lobe of left lung (Fig. 1). Ultrasound-guided pericardiocentesis was performed and $300 \mathrm{ml}$ of pus was drained. Analysis of specimens of pericardium pus indicated WBC of $20 \times 10^{9} / \mathrm{L}$ (100\% neut), lactic dehydrogenase $(\mathrm{LDH})>17,000 \mathrm{IU} / \mathrm{L}$ and glucose of $0.05 \mathrm{mmol} / \mathrm{L}$.
Parenteral treatment with ceftriaxone $2000 \mathrm{mg}$ IV every $24 \mathrm{~h}$ was given at admission, but no clinical improvement was achieved. On the day after his admission the pericardial fluid culture indentified E. corrodens and Streptococcus anginosus, and repeated blood test indicated increased WBC of $28 \times 10^{9} / \mathrm{L}$ and extremely abnormal blood biochemical indexes including alanine aminotransferase (ALT) of 5,000 IU/L, aspartate aminotransferase $(\mathrm{AST})>10,000 \mathrm{IU} / \mathrm{L}, \mathrm{LDH}$ of $10,000 \mathrm{IU} / \mathrm{L}$, amylase of $366 \mathrm{IU} / \mathrm{L}$, and hypoalbuminemia of $25 \mathrm{~g} / \mathrm{L}$. Serum myocardial markers levels increased dramatically (Troponin $\mathrm{T}$ of $198 \mathrm{ng} / \mathrm{L}$ and pro-b-type natriuretic

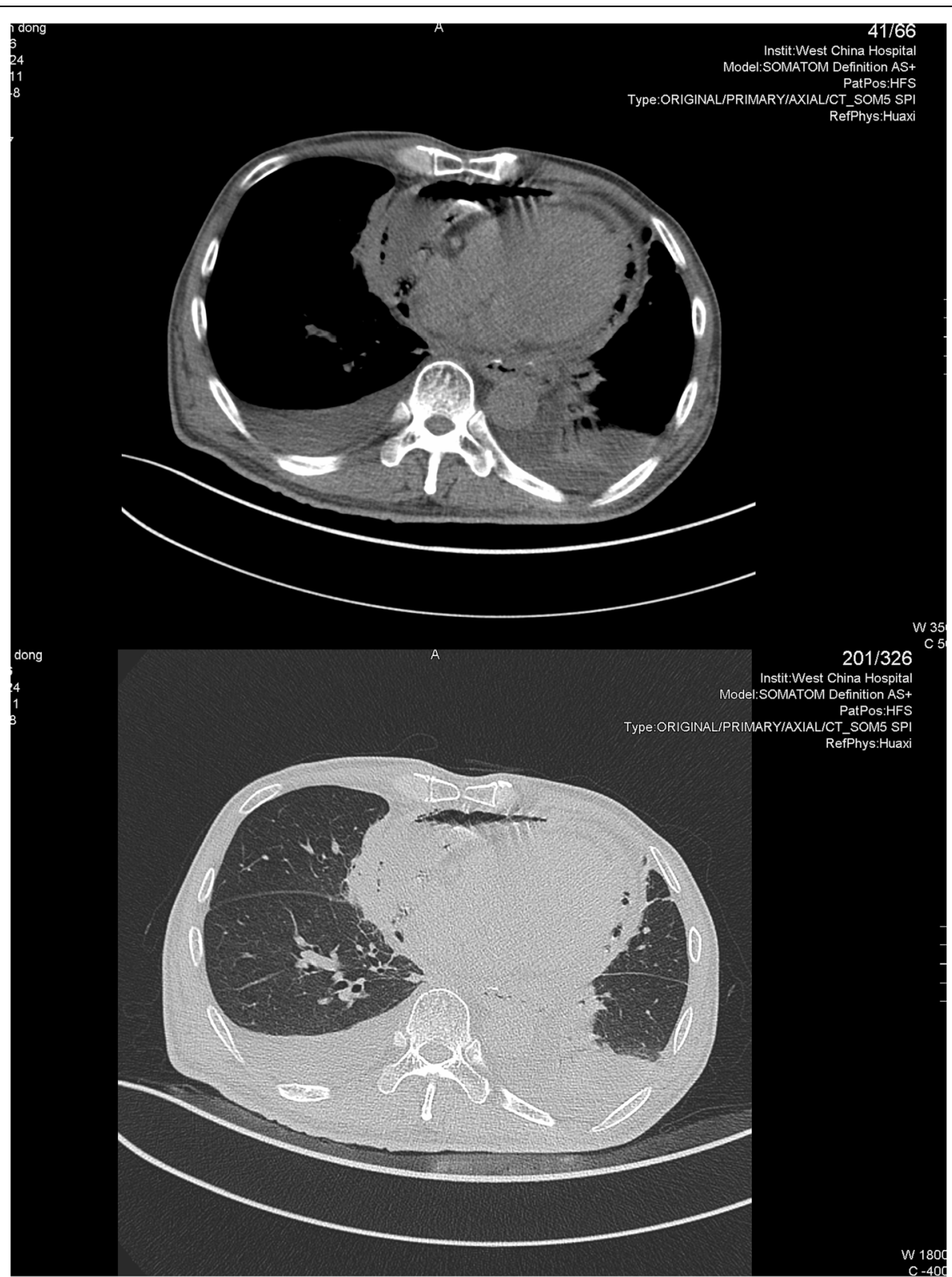

Fig. 1 CT scan of the thorax at mid-thoracic level showing widened mediastinum, pyopneumopericardium, bilateral pleural effusion, and collapse of the lower lobe of left lung 
peptide of $3,000 \mathrm{pg} / \mathrm{ml}$ ). Arterial blood gas analysis revealed apparent acidosis and type I respiratory failure (oxygen partial pressure of $55 \mathrm{mmHg}$, lactate of 9.8 $\mathrm{mmol} / \mathrm{L}$ ). The patient's vital signs worsened on day 2 after admission with blood pressure of $84 / 45 \mathrm{mmHg}$, pulse of $154 \mathrm{bpm}$, respiratory rate of 42 per minute and oxygen saturation of $78 \%$. The antibiotic therapy was changed to imipenem $500 \mathrm{mg}$ IV every $8 \mathrm{~h}$, and mechanical ventilation was provided. But the patient's condition still had no improvement. The antimicrobial susceptibility test showed that the isolated strain was sensitive to imipenem and ceftriaxone, while resistant to clindamycin and amykacin. The patient died three days after admission.

\section{Discussion and conclusion}

Eikenella corrodens is a ubiquitous bacillus of the oral flora. Belonging to the HACEK bacteria group (Haemophilus species, Aggregatibacter species, Cardiobacterium hominis, Eikenella corrodens, and Kingella species), E. corrodens has been shown to cause endocarditis, mediastinitis or pleuropulmonary infections in the thoracic cavity [10-13]. Pericarditis caused by E. corrodens is rare. Only four cases of pericarditis caused by E. corrodens were indentified in a Medline literature search (Table 1). In these cases, the patients were immunocompetent without any evidence of local lesions such as oesophageal perforation. Peritonsillar infection occurred in two cases, and it was suspected as primary sources. The antimicrobial sensitivity and susceptibility test indicated that E. corrodens were commonly resistant to clindamycin but sensitive to ampicillin. With prolonged treatment in these 4 cases reported, the patients had a good prognosis [14-17].

In the case reported here, the port of entry could not be determined. But the past esophageal cancer treated with surgery and radiotherapy and diabetes mellitus may be the important risk factors. The relatively lower level of WBC indicated the patient may be immunocompromised for a long time. Patients with neutropenia may present atypical manifestations of infection, rapid progression of infection, unusual infecting organisms, and unusual sites of involvement [18].

The S. anginosus and E. corrodens, both found in the oral cavity and the gastrointestinal tract may cause localized suppurative infections in different body sites. The interaction between these microorganisms enables them to disrupt the mucosal barrier and invade deeper tissues, which leads to mixed infections, especially in infectious processes with host defenses compromised [19].

According to the antimicrobial sensitivity and susceptibility test, the empirical antibiotic treatment for the patient should be effective. However, the clinical condition of the patient deteriorated quickly after the drainage indicated that the diagnosis, pericardiocentesis and treatment was initiated too late or not at the right time, and the surgery may spread the infection without enough or strong antibiotics treatment previously. Unfortunately, further chest radiography was not obtained to confirm the hypothesis. On the other hand, the unfavorable

Table 1 Clinical features of three patients with pericarditis due to Eikenella corrodens

\begin{tabular}{|c|c|c|c|c|c|c|c|c|c|}
\hline $\begin{array}{l}\text { Case No. } \\
\text { [Reference] }\end{array}$ & $\begin{array}{l}\text { Age/ } \\
\text { Sex }\end{array}$ & $\begin{array}{l}\text { Underlying } \\
\text { condition }\end{array}$ & $\begin{array}{l}\text { Other } \\
\text { associated } \\
\text { organisms }\end{array}$ & $\begin{array}{l}\text { Associated } \\
\text { infection }\end{array}$ & $\begin{array}{l}\text { Medical } \\
\text { treatment } \\
\text { (duration) }\end{array}$ & Clinical context & Outcome & Sensitive & Resistant \\
\hline $1[14]$ & $\begin{array}{l}\text { 28/ } \\
\text { female }\end{array}$ & $\begin{array}{l}\text { Minimal } \\
\text { bronchiectasis }\end{array}$ & no & $\begin{array}{l}\text { mediastinitis, } \\
\text { pneumonia }\end{array}$ & $\begin{array}{l}\text { Amoxycillin } \\
\text { (3 weeks) }\end{array}$ & $\begin{array}{l}\text { Pericardiotomy } \\
\text { and upper } \\
\text { mediastinal drain }\end{array}$ & Cured & $\begin{array}{l}\text { Ampicillin } \\
\text { Gentamicin } \\
\text { Cefuroxime }\end{array}$ & Clindamycin \\
\hline 2 [15] & $\begin{array}{l}52 / \\
\text { male }\end{array}$ & no & $\begin{array}{l}\text { Haemolytic } \\
\text { streptococci } \\
\text { of group A }\end{array}$ & $\begin{array}{l}\text { Peritonsillar } \\
\text { abscesses } \\
\text { pleural } \\
\text { effusion }\end{array}$ & $\begin{array}{l}\text { Ticarcillin } \\
\text { (3 weeks) }\end{array}$ & $\begin{array}{l}\text { Pericardiocentesis } \\
\text { Pleural drainage }\end{array}$ & Cured & Unknown & $\begin{array}{l}\text { Clindamycin } \\
\text { Amikacin }\end{array}$ \\
\hline $3[16]$ & $\begin{array}{l}29 / \\
\text { female }\end{array}$ & Tonsillectomy & no & $\begin{array}{l}\text { pneumonia, } \\
\text { pleuritis, pleural } \\
\text { effusion, } \\
\text { cholecystitis }\end{array}$ & $\begin{array}{l}\text { Moxifloxacin } \\
\text { (3 weeks) } \\
\text { Ceftriaxone } \\
\text { (4 weeks) }\end{array}$ & $\begin{array}{l}\text { Thoracotomy } \\
\text { Pericardiocentesis }\end{array}$ & Cured & Unknown & Unknown \\
\hline $4[17]$ & $\begin{array}{l}32 / \\
\text { male }\end{array}$ & $\begin{array}{l}\text { Bronchomediastinal } \\
\text { fistula }\end{array}$ & no & $\begin{array}{l}\text { Bilateral pleural } \\
\text { effusions }\end{array}$ & $\begin{array}{l}\text { Ampicillin } \\
\text { (4 weeks) }\end{array}$ & $\begin{array}{l}\text { Thoracocentesis } \\
\text { Operative drainage } \\
\text { of the pericardial } \\
\text { sac Debridement } \\
\text { of the left lung, } \\
\text { silicone stent } \\
\text { placement at the } \\
\text { left main bronchus }\end{array}$ & Cured & Ampicillin & Unknown \\
\hline This case & $\begin{array}{l}63 / \\
\text { male }\end{array}$ & $\begin{array}{l}\text { Diabetes mellitus } \\
\text { esophageal cancer } \\
\text { with surgery and } \\
\text { radiotherapy }\end{array}$ & $\begin{array}{l}\text { Streptococcus } \\
\text { anginosus }\end{array}$ & $\begin{array}{l}\text { pneumonia } \\
\text { pleuritis pleural } \\
\text { effusion }\end{array}$ & $\begin{array}{l}\text { Imipenem } \\
\text { (2 days) }\end{array}$ & Pericardiocentesis & Died & $\begin{array}{l}\text { Imipenem } \\
\text { Ceftriaxone }\end{array}$ & $\begin{array}{l}\text { Clindamycin } \\
\text { Amikacin }\end{array}$ \\
\hline
\end{tabular}


outcome could be related to the patient's later age, to the neutropenia induced by recurrent tumors treated with radio and chemotherapy. Furthermore, we inferred that patient's atypical symptoms contributed to the delay in seeking medical service and rapid progression of infection.

The case reported here presents a rare pericarditis caused by E. corrodens. In immunosuppressed host E. corrodens is an important pathogen associated with a spectrum of intrathoracic suppurative infections by itself or as part of mixed flora. Earlier diagnosis and proper drainage surgery with effective antibiotics treatment may improve the prognosis.

\section{Abbreviations}

ALT: Alanine aminotransferase; AST: Aspartate aminotransferase;

LDH: Lactatdehydrogenase

\section{Acknowledgments}

We would like to thank Dr. Mei Kang, the Department of Laboratory

Medicine, for assisting on the pericarditis diagnosis.

\section{Authors' contributions}

HN admitted and treated the patient. WW performed the literature review and drafted the manuscript. HN revised the manuscript. Both authors read and approved the final manuscript. All the authors have accepted responsibility for the entire content of this submitted manuscript and approved submission.

\section{Funding}

None declared.

\section{Availability of data and materials}

The dataset of this article will not be available publicly, to ensure the patient's' privacy, but are available from the corresponding author on reasonable request.

\section{Ethics approval and consent to participate}

This research was approved by the Institutional Research Ethics Committee of West China Hospital. A written informed consent to participate was taken from all participants.

\section{Consent for publication}

The family has given written informed consent for the publication of this manuscript for themselves and on behalf of their patient including the radiology images.

\section{Competing interests}

The authors declare that they have no competing interests.

Received: 4 June 2019 Accepted: 4 July 2019

Published online: 23 July 2019

\section{References}

1. Chen C-KC, Dunfort RG, Reynolds HS, Zambon JJ. Eikenella corrodens in the human oral cavity. J Periodontal Res. 1989;60:61 1-6.

2. Goodman AD. Eikenella corrodens isolated in oral infections of dental origin. Oral Surg Oral Med Oral Pathol. 1977;44:128-34.

3. Goldstein EJC, Citron DM, Wield B, et al. Bacteriology of human and animal bite wounds. J Clin Microbiol. 1978;8:667-72.

4. Drake AF, Wolf GT, Fischer JJ. Eikenella corrodens as a cause of recurrent and persistent infections of the head and neck. Am J Otolaryngol. 1986;7; 426-30.

5. Dorff GJ, Jackson LJ, Rytel NW. Infections with Eikenella corrodens. Ann Intern Med. 1974;80:305-9.

6. Stoloff AL, Gillies ML. Infections with Eikenella corrodens in a general hospital: a report of 33 cases. Clin Infect Dis. 1986;8:50-3.

7. Trallero EP, Arenzana JMG, Eguiluz GC, De Toro Rios P. Extraoral origin of Eikenella corrodens infections. Lancet. 1988;1:298-9.
8. Olopoenia LA, Mody V, Reynolds M. Eikenella corrodens endocarditis in an intravenous drug user: case report and literature review. J Natl Med Assoc. 1994;86:313-5.

9. Yetimoglu C, Rafeiner P, Engel D, Fournier JY. Spinal infections due to Eikenella corrodens: case report and literature review. Neurochirurgie. 2014; 60(4):197-200

10. Das M, Badley AD, Cockerill FR, Steckelberg JM, Wilson WR. Infective endocarditis caused by HACEK microorganisms. Annu Rev Med. 1997;48:25-33.

11. Sharara SL, Tayyar R, Kanafani ZA, Kanj SS. HACEK endocarditis: a review. Expert Rev Anti-Infect Ther. 2016;14(6):539-45.

12. Chambers ST, Murdoch D, Morris A, et al. HACEK infective endocarditis: characteristics and outcomes from a large, multi-National Cohort. PLoS One. 2013;8(5):e63181 Abbate A, ed.

13. Javaheri S, Smith RM, Wiltse D. Intrathoracic infections due to Eikenella corrodens. Thorax. 1987:42:700-1.

14. Hardy CC, Raza SN, Isalska B, Barber PV. Atraumatic suppurative mediastinitis and purulent pericarditis due to Eikenella corrodens. Thorax. 1988 Jun;43(6): 494-5.

15. Zgheib A, el Allaf D, Demonty J, Rorive G. Intrathoracic infections with bacteraemia due to Eikenella corrodens as a complication of peritonsillar abscesses: report of a case and review of the literature. Acta Clin Belg. 1992; 47(2):124-8.

16. Dézsi CA, Kullmann T, Issekutz A, et al. Empyema thoracis, hemorrhagic pericarditis and acalculous cholecystitis caused by Eikenella corrodens sepsis. Orv Hetil. 2013;154(47):1873-6.

17. Smer A, Saurav A, Abuzaid A, et al. Bronchomediastinal fistula presenting as purulent pericarditis in a healthy 32-year-old man. J Cardiol Cases. 2015; 11(1):35-7.

18. Bodey GP. Unusual presentations of infection in neutropenic patients. Int J Antimicrob Agents. 2000;16(2):93-5.

19. Jacobs JA, Algie GD, Sie GH, et al. Association between Eikenella corrodens and streptococci. Clin Infect Dis. 1993;16(1):173.

\section{Publisher's Note}

Springer Nature remains neutral with regard to jurisdictional claims in published maps and institutional affiliations.
Ready to submit your research? Choose BMC and benefit from:
- fast, convenient online submission
- thorough peer review by experienced researchers in your field
- rapid publication on acceptance
- support for research data, including large and complex data types
- gold Open Access which fosters wider collaboration and increased citations
- maximum visibility for your research: over $100 \mathrm{M}$ website views per year
At BMC, research is always in progress.
Learn more biomedcentral.com/submissions 